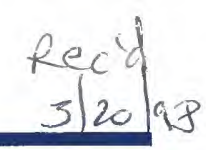

\title{
Watershed and River Systems Management Program
}

A collaborative program is described that couples watershed models providing the physical hydrology from the uplands, routing and reservoir management models accounting for downstream water use, and hydraulic and chemical models identifying reach-specific problems in the riverine environment. Such a linkage yields a powerful water-resource-decision support system.

\section{Introduction}

Competition among water resource users in many basins in the western United States has resulted in a need for near real-time assessments of water availability and use. Use of hydrologic and water-management models is needed to provide these assessments. Advancements in computer hardware and modeling software have enabled the development of water-resource models that can substantially benefit water-resource planning and operation.

The U.S. Geological Survey (USGS) and the U.S. Bureau of Reclamation (Reclamation) are collaborating on the Watershed and River Systems Management Program, which couples watershed and reach models that describe the physical hydrologic setting with routing and reservoir management models that account for water use for improved water-resources assessment.

\section{Database-Centered Approach}

The key to linking these models is a common database which provides a database-centered decision support system (DSS) where output from one model can be written to the database for use as input to another model (fig. 1). The database also links ancillary tools needed by individual models, such as a geographical information system (GIS),

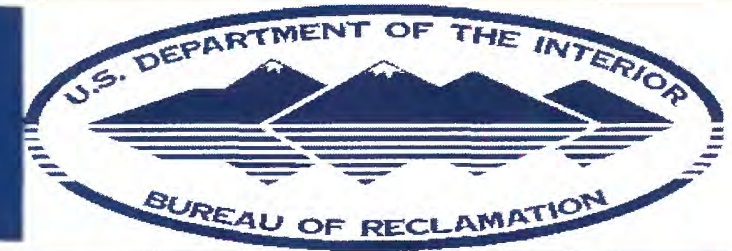

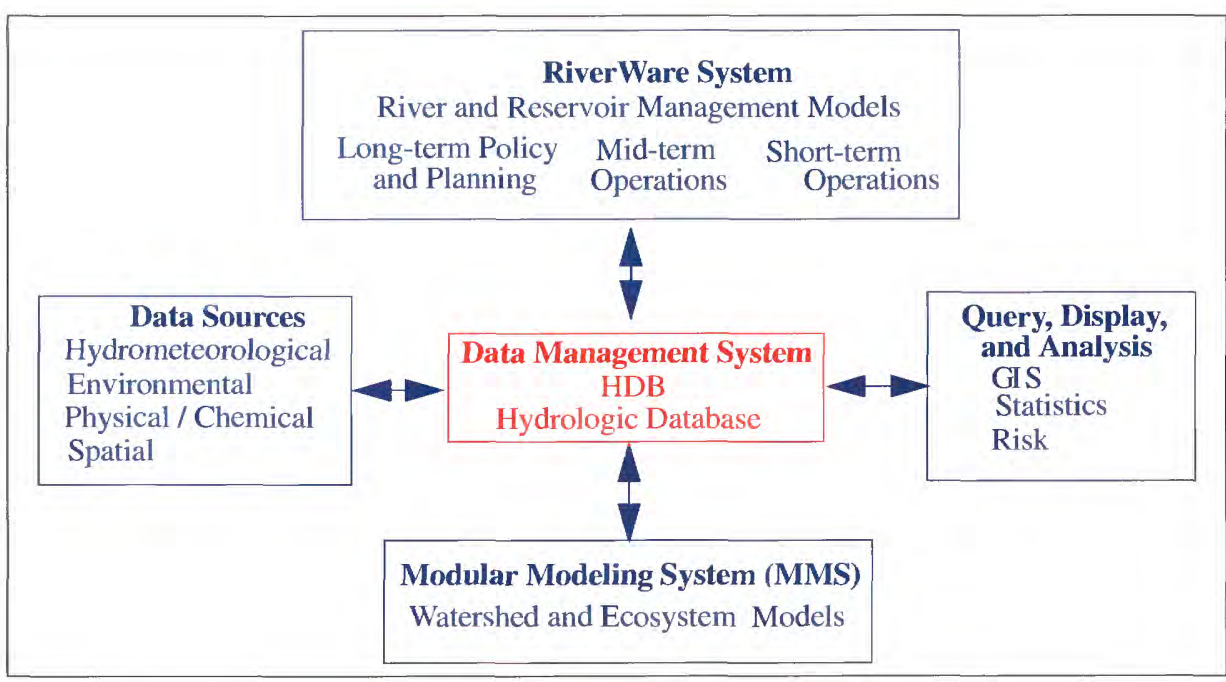

Figure 1. --- Database-centered decision support system

statistical analysis, and data query and display capabilities. The GIS provides an automated method to define values for distributed model parameters, provides animation tools to visualize and analyze the spatial and temporal distribution of simulated state variables, and allows comparisons of these variables with independent measures of their spatial and temporal variation.

\section{San Juan River Basin}

The Watershed and River Systems Management Program is being conducted in the 60,000 square kilometer San Juan River Basin, a subbasin in the Colorado River Basin (fig. 2). The Bureau of Reclamation operates four reservoirs within the San Juan River Basin, and there are six additional reservoirs in the basin, each with storage capacities in excess of 6 million cubic meters. The San Juan River empties directly into Lake Powell, a Reclamation reservoir. The 632,000 square kilometer 
Colorado River basin dominates the water resources of the southwestern United States; water from the Colorado River Basin is used by more than 12 million people and irrigates about 1 million hectares of agricultural land.

The San Juan River Basin has a varied topography and climate that affects quantity and quality of streamflow. Headwater drainages in the San Juan Mountains of Colorado are the major sources of water, but the major water uses occur downstream in the more arid and semi-arid regions of the basin. The San Juan Mountains range in elevation from 1,830 meters to 4,290 meters. Precipitation falls primarily as snow. Orographic effects produce high spatial variability in the amounts of snow in the basin. Mean annual precipitation in the basin ranges from 200 to more than 1,500 millimeters.
MMS has three major components: pre-process, model, and post-process (fig. 3). The pre-process component includes tools used to input, analyze, and prepare spatial and time-series data for use in model applications. The model component includes tools to develop and apply models. The post-process component provides tools to display and analyze model results and to pass results to management models or other types of software. A major feature of the model component is the module library which contains a variety of modules for simulating water, energy, chemical, and biological processes. The user, through an interactive model builder interface (xmbuild), selects and links modules to create a specific model.

The model assembled for the upland watersheds in the San Juan River basin allows for the spatial distribution of hydrologic parameters by partitioning a watershed into hydrologic response units (HRU's). HRU's are assumed to be homogeneous in their

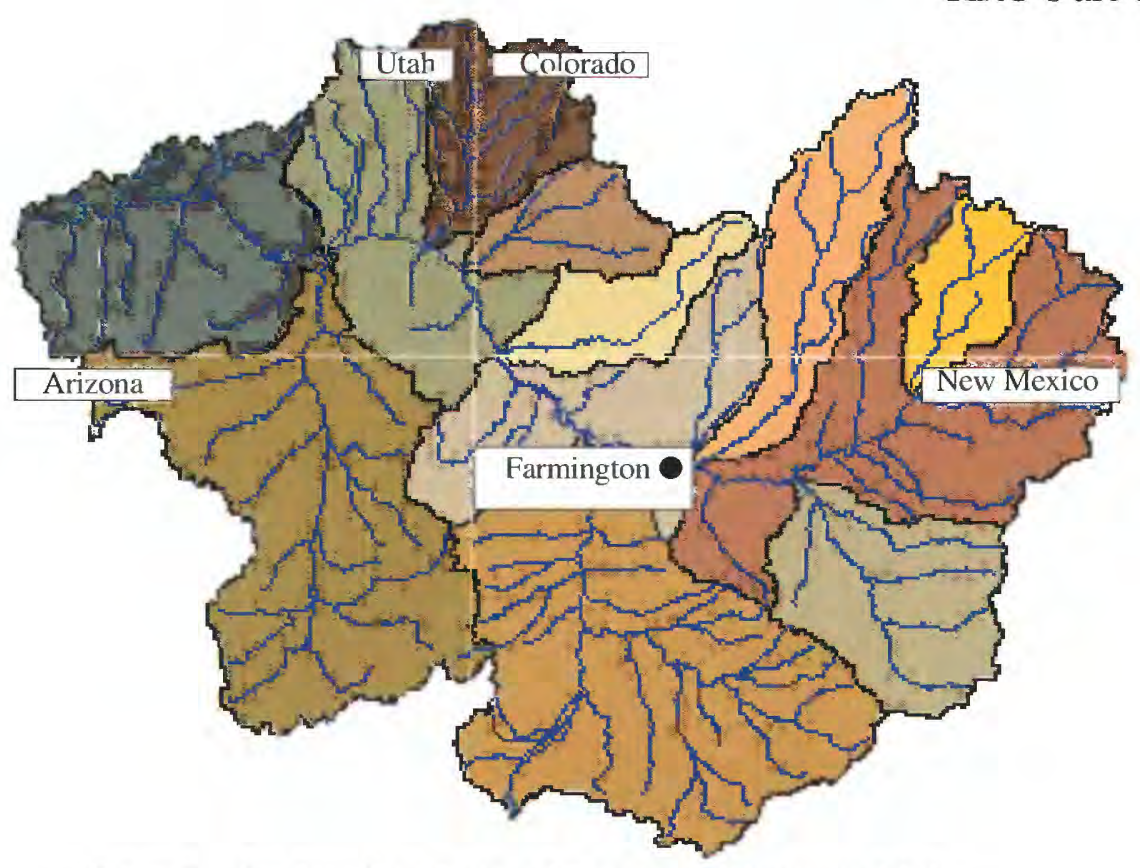

Figure 2. -- San Juan River basin and the major sub-basins modeled. characterized using information about hydrologic response and are topography, soils, vegetation, and precipitation distribution (Leavesley and others, 1983). A daily water balance is computed for each HRU on the basis of model inputs (daily values of air temperature, precipitation, and solar radiation). The responses of all HRU's are summed on a unit-area basis and provide daily streamflow estimates at the outlet of the drainage basin. A geographic information system (GIS) interface is provided to facilitate model development and is termed the GIS Weasel (Leavesley and others, 1997). HRU's are defined for the 18,750 square kilometer area upstream from Farmington, New Mexico. A digital elevation model (DEM) for the San Juan River basin provided the input for automatic delineation of watershed and HRU boundaries. A menu for examining and modifying the HRU map and its attributes is provided. Data derived from the original elevation grid (for example, slope, aspect) or other grids of attribute data (for example, vegetation, soils) can be used to estimate selected HRU parameters. Output from the watershed model is used by the routing and reservoir management component of the DSS, RiverWare.
The USGS Modular Modeling System (MMS) is an integrated system of computer software developed to provide a framework for the development and application of models to simulate a variety of water, energy, and biogeochemical processes (Leavesley and others, 1996). MMS is being used for the watershed modeling component of this study. 


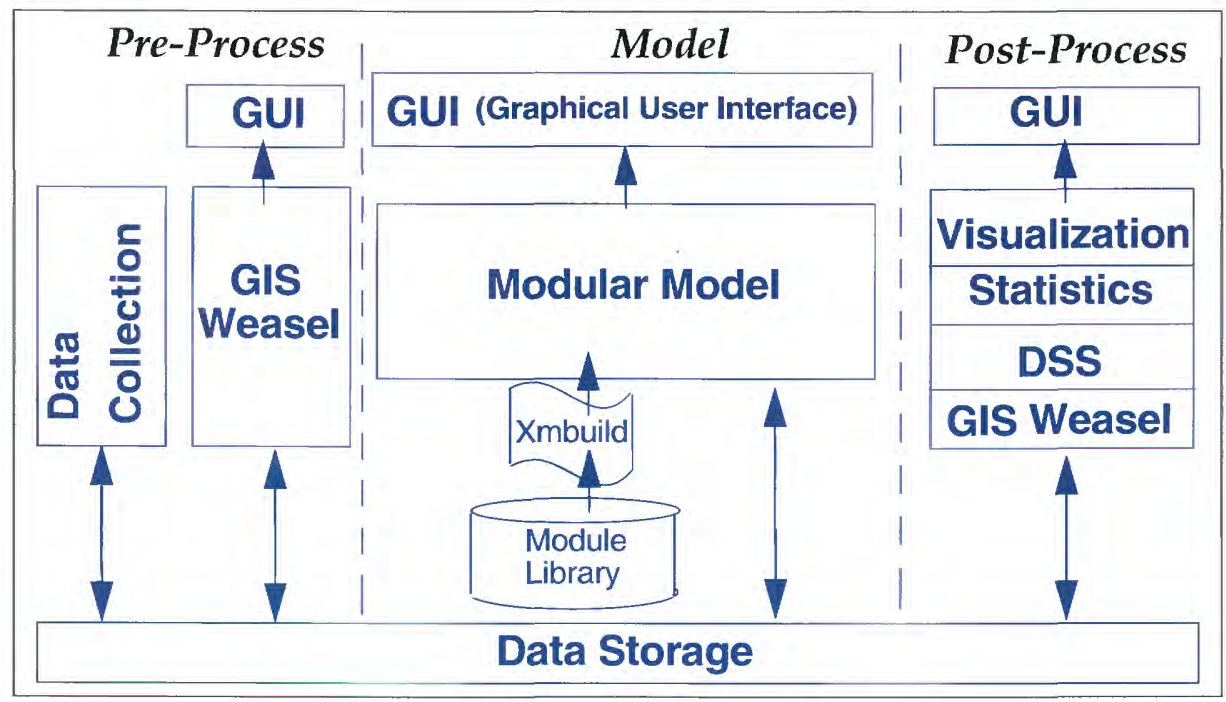

Figure 3. -- Components of the Modular Modeling System (MMS). operations and scheduling, mid-term operations and planning, and long-term policy and planning. The modeling framework was developed by the Center for Advanced Decision Support for Water and Environment Systems (CADSWES) at the University of Colorado with funding provided by Reclamation, Tennessee Valley Authority, and Electric Power and Research Institute (Fulp and others, 1995). Within RiverWare, the user

\section{RiverWare}

The RiverWare Systems Model is the routing and reservoir management model being used in the San Juan River basin (fig. 4). RiverWare is a generalpurpose, interactive model building tool used to develop water distribution models for short-term

\section{constructs the basic network of a river system} that may include reservoirs, diversions, river reaches, confluences, or other components. Data associated with each component can be entered on-screen through spread sheets or imported from the database. The operations policy and rules associated with reservoirs or other system components within the basin are added to RiverWare through an existing constraint editor.

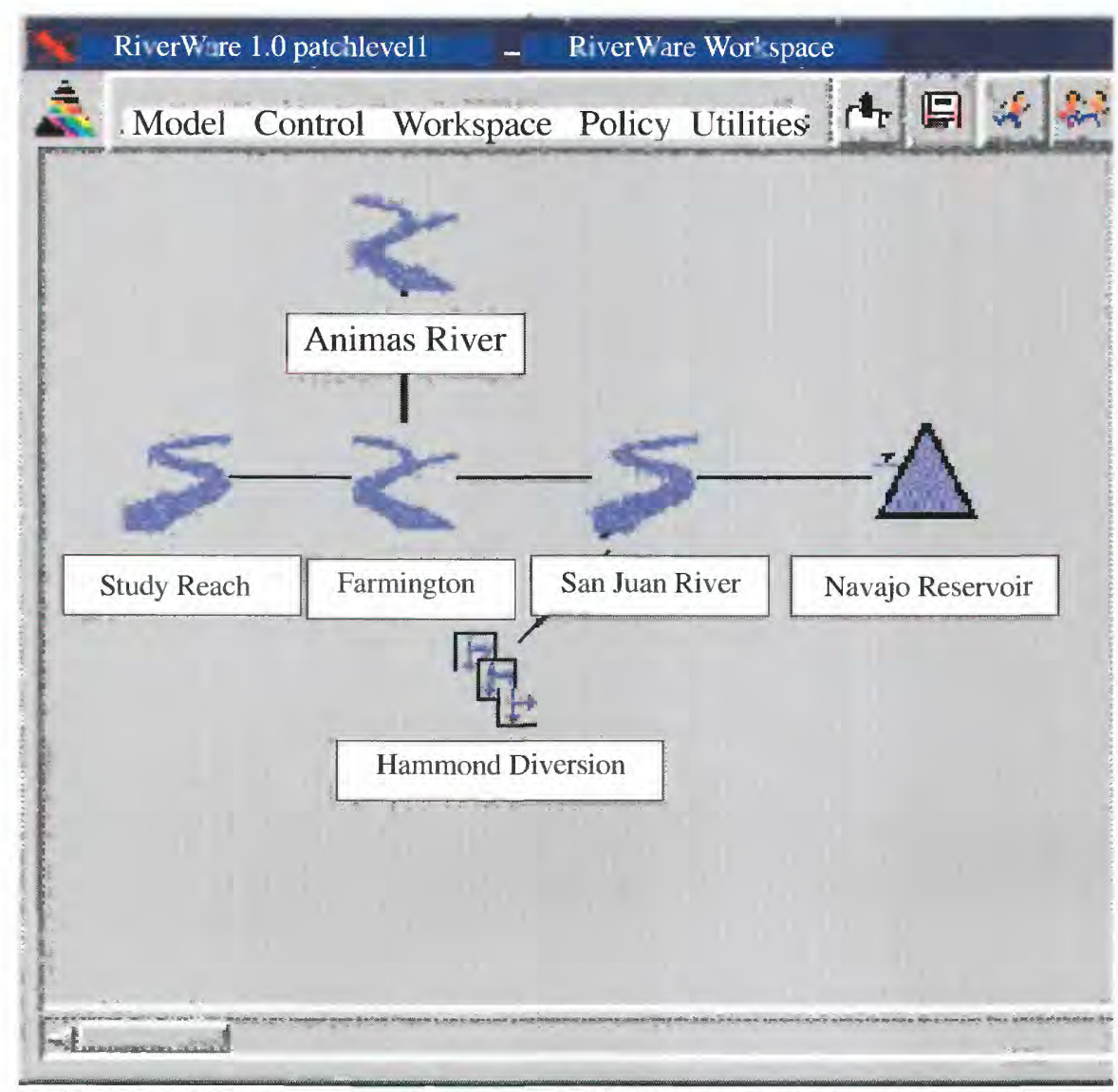

Figure 4. -- Computer screen of RiverWare during model layout of the San Juan River basin. Icons shown are only the intial components of the system.
Current modeling methods within RiverWare include basic reservoir simulation and water distribution through the network using linear programming, goal programming, and rule-based simulation approaches. Water rights allocation is being developed as an additional modeling method. Hourly, daily, weekly, and monthly computational time steps are supported.

\section{Model Linkages}

Many water-management issues including fisheries and water fowl habitat, water quality, and channel maintenance for river recreation need reachspecific hydraulic and chemical information that is conditioned on upstream flows. That is, the detailed hydrology of a given 
reach must include the constraints of the overall physical hydrology and water-management issues within the basin. One way to include these constraints is to use reach-specific models within the modeling sequence. Several reach-specific models are included in MMS and can be linked with watershed-model or RiverWare output. For example, a one-dimensional hydraulic model using daily streamflow from RiverWare, along with detailed local topography and bed-material information, can be used to predict a stage-discharge relation, reachaveraged vertical distributions of velocity, and stress at a cross-section (Nelson and others, 1991). These relations provide the necessary hydraulic input to compute bed-sediment discharge (Parker and others, 1992). Identifying sediment discharge and associated hydraulic conditions and predicting changes that occur with alterations in the hydrograph are critical to an understanding of channel and habitat maintenance.

\section{Future Efforts}

Linking of models in the San Juan River basin provides a way to examine water-resource issues at reach and cross-section scales using streamflows that reflect basinwide water resources. Continued work in the Watershed and River Systems Management Program will be in the Yakima River basin, Washington. The goal is to provide additional algorithms to the modeling packages in order to address additional water resource issues.

\section{References}

Fulp, T.J., Vickers, W.B., Williams, B., and King, D.L., 1995, Decision support for water resources management in the Colorado River region: in L. Ahuja, J. Leppert, K. Rojas, and E. Seely (eds.), Workshop on computer applications in water management, Colorado Water Resources Research Institute, Fort Collins, CO., Information Series No. 79, pp. 24-27.

Leavesley, G. H., Lichty, R. W., Troutman, B. M., and Saindon, L. G., 1983, Precipitation-runoff modeling system-Users manual: U.S. Geological Survey Water-Resources Investigations Report 83-4238, $207 \mathrm{p}$.
Leavesley, G. H., Restrepo, P. J., Markstrom, S. L., Dixon, M., and Stannard, L. G., 1996, The modular modeling system (MMS) — user's manual: U.S. Geological Survey Open-File Report 96-151, 142 p.

Leavesley, G. H., Viger, R.J., Markstrom, S. L., and Brewer, M.S., 1997, A modular approach to integrating environmental modeling and GIS: in Proceedings of 15th IMACS World Congress on Scientific Computation, Modelling, and Applied Mathematics, Berlin, Germany.

Nelson, J. M., Emmett, W. W., and Smith, J. D., 1991, Flow and sediment transport in rough channels, in Shou-Shen Fan and Yung-Huang Kuo, eds., Proceedings of the Fifth Federal Interagency Sedimentation Conference, Vol. 1, p. 4-55 to 4-62.

Parker, R.S., Nelson, J.M., Elliott, J.G., and Carey, W.P., 1992, Changes in bed mobility due to altered streamflows in cobble-bedded mountain streams in the Gunnison River basin: EOS, Transaction of American Geophysical Union, v. 73, no. 43, p. 239.

-R.S. Parker

\section{For additional information contact:}

U.S. Geological Survey:

Randy Parker, (303)236-4882, ext. 295

e-mail: rsparker@usgs.gov

George Leavesley,(303)236-5026 e-mail: george@usgs.gov

John Vaccaro, (206)593-6510 e-mail: jvaccaro@usgs.gov

Bureau of Reclamation:

Terry Fulp,(303)492-8572 e-mail: tfulp@cadswes.colorado.edu

Don Frevert,(303)236-0123, ext. 225 e-mail: dfrevert@ibr8gw80.usbr.gov 